\title{
Comparative Analysis of Sustainability in Paddy Monoculture and Paddy-Maize Rotation Farming Systems in Sri Lanka
}

\author{
S.P. Dissanayake ${ }^{1 *}$, L.H. P. Gunaratne ${ }^{2}$, T. Sivanathewerl ${ }^{2}$ and G.A.S Ginigaddara ${ }^{1}$ \\ ${ }^{1}$ Faculty of Agriculture, Rajarata University of Sri Lanka, Anuradhapura, Sri Lanka. \\ 2 Faculty of Agriculture, University of Peradeniya, Sri Lanka.
}

\section{ARTICLE INFO}

\section{Article history:}

Received: 31 July 2020

Revised version received: 31 January 2021

Accepted: 02 February 2021

Available online: 30 July 2021

\section{Keywords:}

Farming systems

Paddy-maize rotation

Paddy monoculture

Sustainability

\section{Citation:}

Dissanayake, S.P., Gunaratne, L.H.P., Sivanathewerl, T. and Ginigaddara, G.A.S. (2021). Comparative analysis of sustainability in paddy monoculture and paddy-maize rotation farming systems. Tropical Agricultural Research, 32(3): 265-275.

DOI: http://doi.org/10.4038/tar.v32i3.8490

Dissanayake, S.P.

https://orcid.org/0000-0001-7212-2734

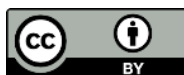

\section{ABSTRACT}

The use of composite indicators is considered to be a unique approach for evaluating the sustainability of farming systems. This study attempted to compare the sustainability of paddy monoculture and paddy-maize rotation farming systems in the Anuradhapura district through developing indicators for economic, social, and environmental sustainability. Using a cluster sampling method, 100 farmers randomly from each farming system. Data collected through a pre-tested questionnaire were analyzed using quantitative and qualitative techniques. According to the Total Sustainability Index (TSI), $72 \%$ of the farmers of paddy monoculture farming systems and $83 \%$ of the farmers of paddy-maize rotation farming systems were sustainable with TSI ranging from 0.5 to 1 . Regression results revealed that cost of production per acre, off-farm income, distance to public infrastructure, agrochemical usage per acre, level of integrated pest management were significantly $(\mathrm{p}<0.05)$ influencing on the paddy monoculture farming system; whereas total on-farm income per acre, distance to public infrastructure, agrochemical use per acre, level of integrated pest management for paddy-maize rotation farming system were significantly $(\mathrm{p}<0.05)$ influencing on the sustainability of paddy-maize rotation system. The study concludes that both the paddy-maize rotation system and paddy monoculture farming system are sustainable while the paddy-maize rotation farming system reflects higher sustainability in the Anuradhapura district, Sri Lanka.

\footnotetext{
*Corresponding author: disasampa@yahoo.com
} 


\section{INTRODUCTION}

Rice is the staple crop in Sri Lanka. It occupies 34\% $(0.77 /$ million ha) of the total cultivated land area in Sri Lanka. On average 560,000 hectares are cultivated during Maha season and 310,000 ha during the Yala season making the average annual extent sown with rice to about 870,000 ha. About 1.8 million farm families are engaged in paddy cultivation island-wide. Sri Lanka currently produces 2.7 million tons of row rice annually satisfying around 95 percent of the domestic requirement (RRDI, 2016). In the Anuradhapura district, 93,537 acres were occupied for paddy cultivation and 3,505,000 bushels were produced in the 2016/ 2017 Maha season (Department of Census and Statistics report, 2016). The current cost of production of rough rice which whole rice grain after harvesting from the rice plant is Rs. 8.57 per $\mathrm{kg}$. The farm power, tradable inputs, and cost of labor constitute $23 \%, 23 \%$, and $55 \%$ of the cost of production respectively. The labor cost has risen at a higher rate than other costs over the last few years (RRDI, 2016).

Maize is primarily a rainfed crop cultivated in the Maha season in both settled and shifting types of highland cultivations. The primary sources of demand for maize are the rural farming population, where maize is consumed either as grains or green cobs and about $25 \%$ of it is used to manufacture poultry feed. Maize is mainly cultivated in six districts in Sri Lanka. Those districts are Anuradhapura, Ampara, Badulla, Moneragala, Matale, and Batticaloa, where the total cultivating area is over 2000 ha. The "maize belt" connecting these districts consists of more than $80 \%$ of the total maize cultivated lands in Sri Lanka. The national extent of maize is 23,000-28,000 ha and the annual production is around 196,000 tons in 2016. There is a wide variation in yield among districts, ranging from $0.14 \mathrm{t} / \mathrm{ha}$ to $6.18 \mathrm{t} / \mathrm{ha}$ (Ranaweera et al., Undated).

Paddy and maize farmers in Sri Lanka are facing several problems concerning production. Climate change is a major problem in paddy production. Especially in Dry zone, farmers are uncertain about cultivating in the Yala season due to persisting drought. Receiving lower prices for paddy and maize is another problem. With those problems, the sustainability of paddy production has gone down (Ranaweera et al., Undated).

In the paddy-maize rotation system, paddy is cultivated one season, and maize is cultivated in the next season. Since 1970, many countries have cultivated high-yielding rice varieties. In some areas, a surplus is happening. Because of that, both domestic and world prices are declining. As a solution for it, the Food Fertilizer Technology center (FFTc) started a four years project to provide farmers with information on profitable ways in which they can make more intensive use of paddy fields. They introduced maize crop to cultivate in the paddy field during their offseason. Because there is a good demand for maize in Asia as livestock feed. More diverse cropping patterns lower the risk than a single commodity. Because of that farmers can respond more efficiently to market forces (FFTc, 2017).

\section{Sustainable Agriculture}

Sustainable agriculture can be defined as an integrated system of plant and animal production practices having a site-specific application that will, over the long term: satisfy human food and fiber needs; improve environmental quality and the natural resource base upon which the agricultural economy depends; make the most efficient use of non-renewable resources and onfarm resources and integrate, where appropriate, natural biological cycles and controls; sustain the economic viability of farm operations; and enhance the quality of life for farmers and society as a whole (Food, Agriculture, Conservation, and Trade Act, 1990). According to a comprehensive view of sustainability, it must involve many factors, and there is broad consensus that these factors should incorporate three elements; economic, environmental, and social known as the sustainability tripod (Vanloon et al., 2005).

The problem of sustainable development is discussed; in science, which is concentrated particularly on the analysis of unsustainable state; and in policy, which deals with regulations and strategies toward sustainability (Hanus, 2003). Therefore, sustainability analysis is necessary for the sustainable development of agriculture. Further, formal assessment systems for agricultural sustainability are necessary for a scientific understanding of policy and planning for sustainable agricultural development. Analytical frameworks for environmental assessments and rural livelihoods assessments, backed by significant international initiatives, have been available for the past decade. Agricultural sustainability assessments can advantage importantly from an understanding of such frameworks (Rao and Rogers, 2006). 


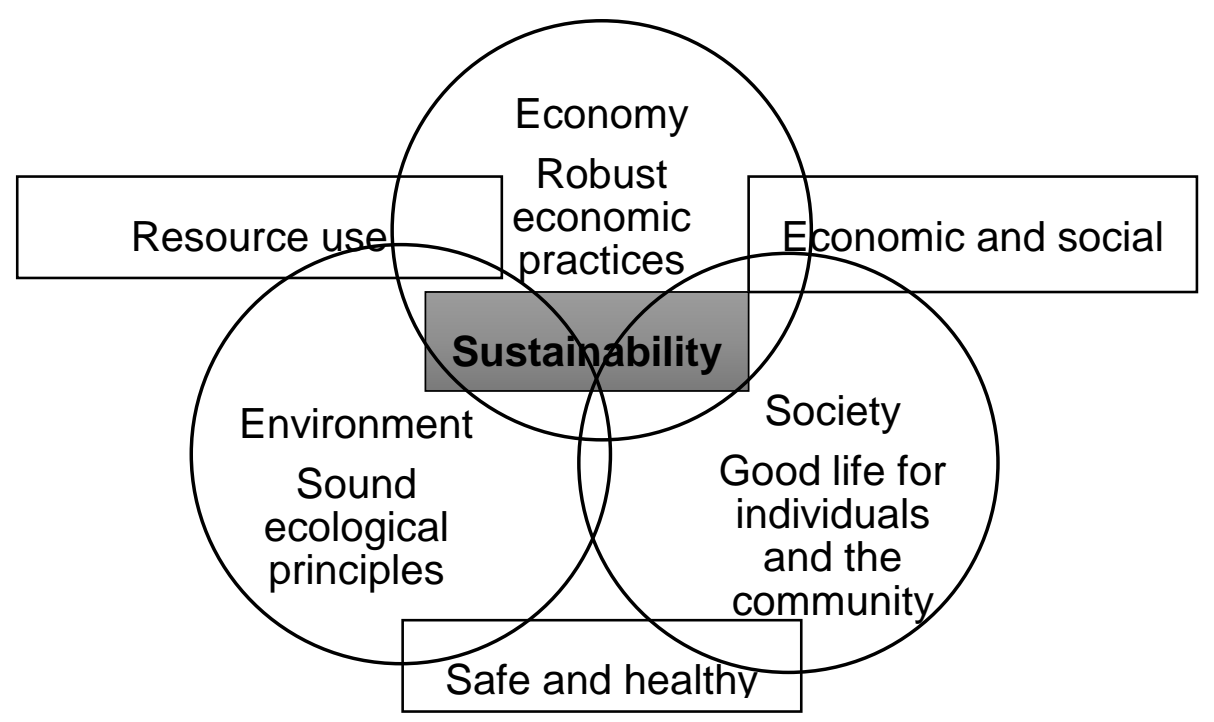

Figure 1: Interactive components of sustainable development. (Source. Vanloon et al., 2005)

\section{Sustainability Assessment Framework}

To conduct sustainability analysis or any other analysis, a framework is necessary to fulfill targets. Sala et al., 2015, (2015) introduced a common framework for sustainable analysis. According to Sala et al., a sustainable assessment framework mainly comprises four steps which are the approach to sustainability, the sustainability targets, the decision context, and methodological choices.

Selections of particular indicators of the impact of the environmental, social, and economic intervention of farming systems? are the crucial steps, when conducting a sustainability assessment. The reason for that is indicator should be location-specific (Dumaski and Pieri, 1996).

\section{Agricultural Sustainability Indicators}

In the global context, preliminary indicators were developed to assess agricultural sustainability. The preliminary indicators meet the following suitability criteria; 1) Social and policy relevance; 2) Analytical soundness and measurability; 3) Suitable for different scale such as farm, district, country, etc.; 4) Encompass ecosystem processes and relate to process-oriented modeling; 5) Sensitive to variations in management and climate and; 6) Accessible to many users (Nambiar et al., 2001). When conducting the sustainable assessment, indicators should be selected as environmental, social, and economic to assess the main pillars of sustainability.

\section{Environmental Indicators}

Environmental indicators are used to measure environmental sustainability. In a study involve with sustainable analysis of ecological and conventional agricultural systems in Bangladesh; Investigators have used land-use patterns, cropping patterns, soil fertility management, management of pests and disease, and soil fertility as an ecological indicator for their study (Rasul and Thapa, 2003). This study used the amount of organic manure usage, amount of chemical fertilizer usage, amount of agrochemical usage, level of adoption of Integrated Pest Management, and level of adoption of Good Agricultural Practices as environmental indicators.

\section{Social Indicators}

Social indicators are used to measure social sustainability. Scientists have used input selfsufficiency, equity, food security, and the risk and uncertainties involved in crop cultivation (Rasul and Thapa, 2003). Cropping diversification and diversity of agricultural income have been used to examine risk and uncertainty indicators. This study used income, access to public infrastructure, and women's participation as a social indicator. 


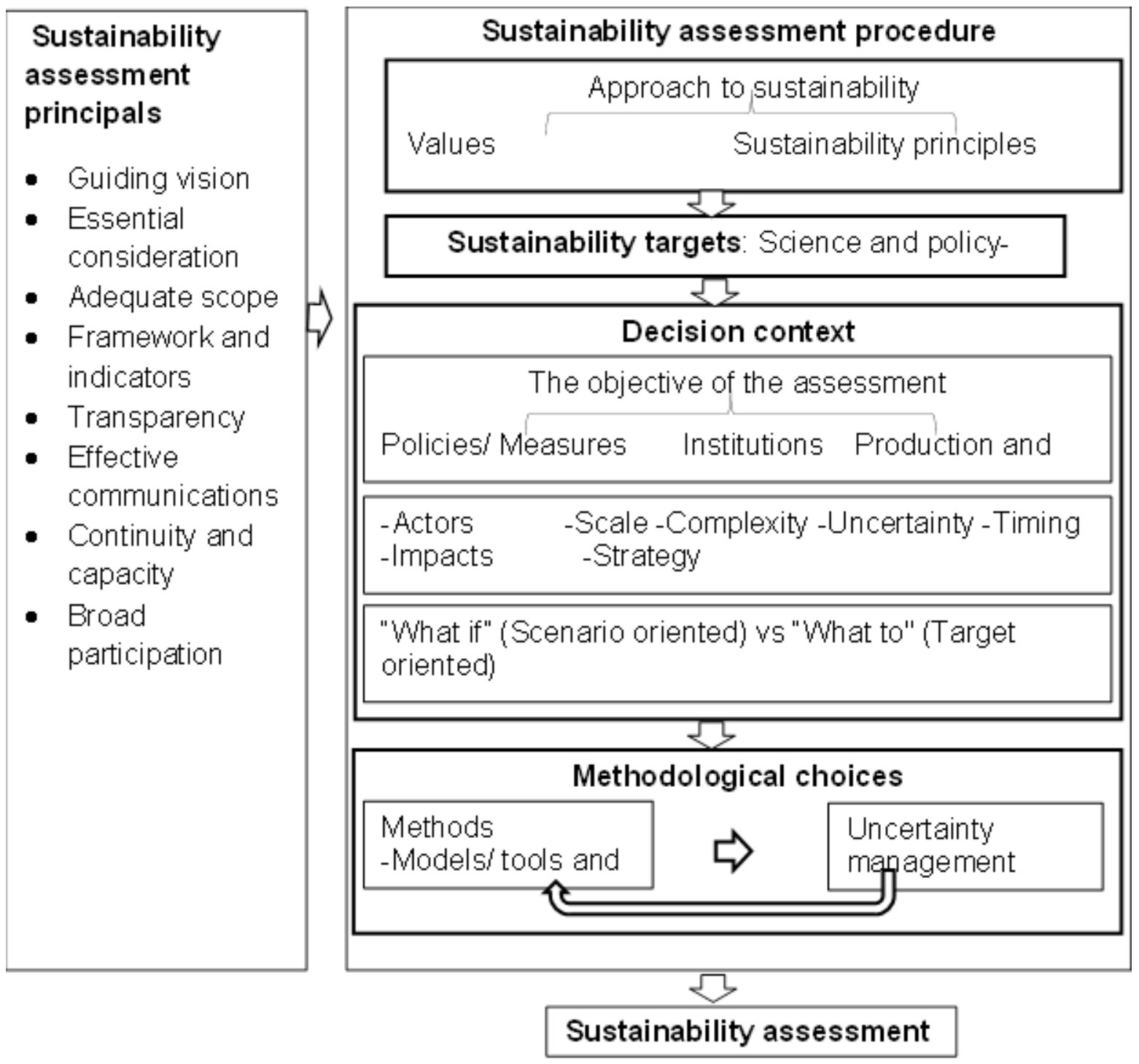

Figure 2: Common Frameworks for Sustainability Assessment. (Source: Sala et al., 2015)

\section{Economic Indicators}

Economic indicators are used to measure economic sustainability. Investigators have used land productivity, the stability of crops, and farm profitability. Land productivity has been measured through the physical yield of crops (Rasul and Thapa, 2003). The stability of crop yield has been examined by constructing an index based on farmers' subjective responses to a question related to yield trends. Financial return, economic return, and value addition per unit of land have been used to measure farm profitability indicators. This study used crop productivity, income-yield, and costbenefit ratio to measure economic sustainability.

Prevailing Issues in Paddy Monoculture and Paddy-Maize Rotation Systems
The Green Revolution consisted of the introduction of fertilizer-responsive, lodging, and diseaseresistant and high-yielding varieties; investments in irrigation infrastructure; increased use of chemical fertilizers, herbicides, insecticides, and fungicides, and government support through extension and micro-credit provisions. Due to the long-term usage of agricultural inputs such as chemical fertilizer, weedicide, pesticide, insecticide, etc. the fertility of the soil gets diminished. Therefore, to maintain the sustainability of paddy fields it is required to practice environmentally friendly methods.

Dry zone farmers are using paddy-maize rotation farming systems throughout the year as the main solution for the water inadequacy for paddy cultivation. Although the Government has launched 
a massive program for chemical-free agriculture stepping towards sustainable production, simultaneously the paddy storage problem has skyrocketed. Though thousands of farmers connected with toxin-free agriculture and reaped good production in the Maha (2016) the tragedy was that the large quantities of paddy from the earlier Yala (2016) harvest were also there in cold storage. The result was the desperate farmers selling their paddy to private mill owners at a low rate to meet their basic needs and failing to get a fair price.

Similarly, two major constraints namely; lack of marketing facilities and not receiving fair prices could be recognized in maize cultivation too. As well as, the sustainability of agriculture and relevant livelihood is strongly dependent on external support. The government and other external agencies are providing several supports to adapt farmers towards more sustainable cultivations. But still, there is a gap between the current level of external supports and farmers' capability to adapt to changes towards sustainable farming.

Therefore, sustainability analysis of the above two farming systems is needed to know the level of sustainability of them and to plan for strategies to enhance the sustainability of them which will also contribute to overcoming the problems related to the two farming systems. Also, sustainability assessment helps decision-makers and policymakers to decide what action they should take and should not take to maintain the production system more sustainable. Furthermore, there is a lack of studies on sustainability analysis of these farming systems which may be mainly due to analyzing sustainability of very complex and locationspecific. Dumaski and Pieri (1996) have proposed different parameters for measuring sustainability and recommended constructing specific parameters according to location-specific ecological and socioeconomic conditions. Hence the study will aim to develop various sustainability indicators for paddy monoculture and paddy maize rotational farming systems to assess and forecast the levels of sustainability which will assist in planning strategies to enhance the sustainability of the systems and national policy review/development with three specific objectives; 1). to identify the socio-economic characteristics of farmers in paddy monoculture and paddy- maize rotation farming systems in Anuradhapura district 2). to assess overall sustainability of paddy monoculture and paddymaize rotation farming system 3 ). to explore the factors affecting the sustainability of paddy monoculture and paddy-maize rotation farming system in Anuradhapura district.

\section{METHODOLOGY}

\section{Study Area}

Anuradhapura district is bounded the North by Vavuniya, Mannar, and Mulathiu districts and to the South by Kurunagala and Mathale districts and to the West by Puttalam and Mannar districts, and to the East by Polonnaruwa and Trincomalee districts were selected for the study. Anuradhapura is the largest administrative district that covers $11 \%$ of the total land area in Sri Lanka. The density of the district is around 717900 hectares and the population is around 856,232. The district is consisting of 7 Electorates, 22 Divisional Secretariats, 41 Agrarian Service Center, and 694 Grama Niladhari Divisions.

\section{Sampling Procedure}

The cluster sampling method was used to select the sample. At the first stage, Divisional Secretariat Divisions were selected purposely as Thalawa, Galenbidunuwewa, and Kahatagasdigiliya for paddy monoculture and Horowpothana and Galenbidunuwewa for paddy-maize rotation system. The reason for that is, most of the agrarian communities have emerged around these areas. In the second stage, Agrarian Services Divisions (15) which cover $50 \%$ of the total farmer population were selected purposely for two farming systems. Finally, at the third stage, 200 (100 farmers for each farming system) farmers were selected randomly from Grama Niladhari divisions in selected Agrarian Service Centers in the Anuradhapura district.

\section{Method of Data Collection}

Key personal interviews and household surveys were adopted and questionnaires were used mainly in primary data collection. The questions were aimed at finding out the sustainability of paddy monoculture and paddy-maize rotation systems in the study area. The structured questionnaires were designed to collect information on the economic indicator, social indicator, and ecological indicator related to the sustainability of the particular systems. Required secondary data were extracted from the Department of Agriculture, Department of Census and Statistics, published and unpublished data sources, internet, and other sources. 


\section{Data Analysis}

Both qualitative and quantitative methods were used for data analysis. The use of both methods ensures that the data were effectively interpreted using the numbers, tables, figures as well as narratives. Descriptive analysis was used to identify the characteristics of paddy monoculture and paddy-maize rotation farming systems in the Anuradhapura district.

The three dimensions of sustainability of farming systems were considered in the study to measure the composite sustainability indices of households (Economic, Social, Ecological sustainability indices). Economic Efficiency Index (EEI) as a measure of economic sustainability, Social Security Index (SSI) as a measure of social sustainability, and Ecological Security Index (ESI) as a measure of ecological sustainability of the farming system in the study area.

Three indicators were developed for economic sustainability namely crop productivity, Incomeyield, and cost-benefit ratio (Table 1). For social sustainability, household income, access to agrarian services, and women's participation in farming were developed. Five indicators were developed for environmental sustainability namely the amount of organic manure usage, amount of chemical fertilizer usage, amount of agrochemical usage, level of adoption of IPM, and level of adoption of GAP.

The following equation was used to normalize the value of each indicator which was used to measure EEI, SSI, and ESI.

$\mathrm{Ij}=1-\left[\left(\mathrm{Xj}_{\mathrm{j}}-\operatorname{Min} \mathrm{Xj}\right) /(\operatorname{Max} \mathrm{Xj}-\operatorname{Min} \mathrm{Xj})\right]$

Where;

$\mathrm{Xj}$ is value of each indicator variable for individual observations; $\mathrm{Min} \mathrm{Xj}$ is sample minimum; $\mathrm{Max} \mathrm{Xj}$ is sample maximum ; Ij is value of jth variable of EEI/SSI/ESI. The EEI/SSI/ESI was computed as the simple mean of their respective individual variables.

Ex. EEI $=\sum n \mathrm{j}=1 \mathrm{Ij} / 3$ ( Three indicators were used in calculating EEI)
The Total Sustainability Index (TSI) was computed as the simple mean of the respective sustainability index (EEI/SSI/ESI) individual variable;

TSI $($ EEI $/$ SSI $/$ ESI $)=\sum \mathrm{nj}=1 \mathrm{Ij} / 3$

Finally, using the criterion of total sustainability index value farming systems were categorized into sustainable (sustainability index $\geq 0.5$ ) or vulnerable (sustainability index $<0.5$ ). Nazir, Kharkwal, Bardhan, Tripathi, and Kumar (2017) assessed the sustainability of dairy production systems in the Uttarakhand Hills of India. They have used the same methodology to assess sustainability. They have used a simple average method to assess the Economic Efficiency Index, Social Security Index, Ecological Security Index, and Total Sustainability Index of dairy production systems. A multiple regression equation has been used to identify the factors significantly influencing sustainability in the dairy production system.

A multiple regression equation was fitted to identify the factors significantly influencing sustainability in each farming system.

$\mathrm{TSI}=\mathrm{f}\left(\mathrm{X}_{1}, \mathrm{X}_{2}, \mathrm{X}_{3}, \ldots . ., \mathrm{D}\right)$

Where;

TSI is Total Sustainability Index; $\mathrm{X}_{1}, \mathrm{X}_{2}, \mathrm{X}_{3}$ are Factors affecting sustainability; D is Dummy variable if have.

\section{RESULTS AND DISCUSSION}

\section{Socioeconomic Characteristics of Farmers}

Results revealed that $89 \%$ of respondents were males and $11 \%$ were females in paddy monoculture farming systems. In the paddy-maize rotation system, $99 \%$ of respondents were males and $1 \%$ were females. According to the results, most of the respondents were males in both farming systems. Other than that, a high number of females engaged in paddy monoculture than paddy-maize rotation system. Of the total respondents of each farming system, $89 \%$ of respondents were married, $5 \%$ were widowed and $6 \%$ were single in the paddy monoculture farming system. In the paddy-maize rotation system, 99\% of respondents were married and $1 \%$ were single. 
Table 1: Selected Indicators Used to Measure the TSI

\begin{tabular}{|c|c|}
\hline Indicator & Description \\
\hline \multicolumn{2}{|l|}{ Economic } \\
\hline Crop Productivity & $\begin{array}{l}\text { Summation of the yield of primary product grown within area } \\
\text { per total area }\end{array}$ \\
\hline Income yield & $\begin{array}{l}\text { Summation of net income per hectare for each crop grown } \\
\text { area per total land area }\end{array}$ \\
\hline Cost-Benefit Ratio & The ratio between profit and total cost \\
\hline \multicolumn{2}{|l|}{ Social } \\
\hline Income & $\begin{array}{l}\text { The ratio between income earned from the farming system and } \\
\text { total household income }\end{array}$ \\
\hline Access to Agrarian Services & $\begin{array}{l}\text { Nearest distance from the household for Agrarian Service } \\
\text { Center }(\mathrm{Km})\end{array}$ \\
\hline Woman's participation & $\begin{array}{l}\text { The ratio between total working hours of women and total } \\
\text { working hours in farming }\end{array}$ \\
\hline \multicolumn{2}{|l|}{ Environmental } \\
\hline Organic manure usage & Amount of organic manure usage per unit area \\
\hline Usage of chemical fertilizer & $\begin{array}{l}\text { Amount of chemical fertilizer used per unit of cropped land } \\
(\mathrm{kg} / \mathrm{acre})\end{array}$ \\
\hline Usage of agro-chemicals & $\begin{array}{l}\text { Amount of agrochemicals used per unit of cropped land } \\
\text { (l/acre) }\end{array}$ \\
\hline Integrated Pest Management (IPM) & Level of adoption of IPM \\
\hline Good Agricultural Practices (GAP) & Level of adoption of GAP \\
\hline
\end{tabular}

The mean age of respondents who engaged in paddy monoculture farming was 51 years (standard deviation was 12.33), minimum and maximum ages were 21 and 73 years respectively. The mean age of respondents who engaged in the paddy-maize rotation system was 50 years (standard deviation was 10.01), minimum and maximum ages were 30 and 78 years respectively.

The education level of the farmers is an important socio-economic character that directly affects the decision-making of farmers in farming. When considering the results of farmers who engaged in paddy monoculture farming system, $41 \%$ of respondents did schooling up to ordinary level, $25 \%$ of farmers did schooling up to grade 1 - grade 5 (Primary education), $23 \%$ of farmers did schooling up to grade 6 -grade $10,8 \%$ of farmers completed advanced level, only one percent of farmers educated up to degree level, $1 \%$ of farmers who had no school education, but they can read easily and also $1 \%$ of farmers had no school education but, they can read with difficulty. Further, the result of the paddy-maize rotation farming system, $57 \%$ of farmers did schooling up to ordinary level, $21 \%$ of farmers did schooling up to grade 6 - grade $10,11 \%$ of farmers completed advanced level, $10 \%$ of farmers did schooling up to primary education (grade 1 - grade 5), only one percent of farmers had educated up to degree level. In summation, most of the farmers completed their ordinary level in both farming systems.

Results revealed that $88 \%$ of respondents engaged in full-time farming, $9 \%$ was engaged in the government sector, $3 \%$ worked in the private sector as their primary occupation in the paddy monoculture farming system. In the paddy-maize rotation system, $89 \%$ of respondents had practiced farming, $11 \%$ had engaged in the government sector as their primary occupation. Most of the respondents (89\%) practice farming as their main occupation in both farming systems while several respondents (11\%) practice farming as a part-time occupation. Moreover, 91\% of respondents had their land and $9 \%$ had utilized tenant land for paddy monoculture farming systems. In the paddymaize rotation farming system, $97 \%$ of 
respondents had their lands and only 3\% had utilized tenant land.

The result indicates that the mean land extent of respondents Is 2.5 acres (standard deviation IS 1.14) and the land extent ranges from 15.5 acres in a total sample of paddy monoculture farming system. In the paddy-maize rotation system, the mean land extent of paddy cultivation is 4.1 acres (standard deviation was1.23), land extent ranges from 1-6 acres, and the mean land extent where maize is cultivated in 2.9 acres (standard deviation was 1.26), land extent was ranged with 1-6 acres.

Selected respondents for this study have earned their agricultural income from paddy monoculture farming or paddy-maize rotation farming. The mean annual agricultural income (per acre) is Rs.68,364.00, an annual agricultural income range within Rs. 41,714.00-Rs.108,550.00 in paddy monoculture farming system. In paddy-maize rotation system, mean annual income (per acre) is Rs.166,770.00 and annual agricultural income ranges within Rs.118,552.00-Rs.304,575.00. In summation, respondents who are engaged in the paddy-maize rotation system had earned high agricultural income than respondents who are engaged in the paddy monoculture farming system. The mean annual off-farm income in paddy monoculture and paddy-maize rotation systems are Rs. 133,680.00 and Rs.138,576.00 respectively (Table 2).

\section{Comparison of Sustainability of Paddy Monoculture and Paddy-Maize Rotation System}

Total Sustainability Index was measured by taking a simple average of the three sub-indices. Results revealed that $72 \%$ of respondents were sustainable (TSI $\geq 0.5$ ) and $28 \%$ were vulnerable (TSI $<0.5$ ) in paddy monoculture farming systems. In the paddy-maize farming system, $83 \%$ of respondents were sustainable (TSI $\geq 0.5$ ) and $17 \%$ were vulnerable $(\mathrm{TSI}<0.5)$. In summation, both paddy monoculture and paddy-maize systems are sustainable. However, the paddy-maize rotation system was more sustainable than the paddy monoculture system.

The rotation system showed lower pest attacks and diseases as crop rotation causes pests' annual life cycle to disrupt. Due to that, the usage of pesticides and insecticides are reduced and therefore beneficial organisms are protected while increasing food quality and the health of humans.
In the paddy-maize rotation system, these crops require different environmental conditions. Stagnant water conditions are best for rice cultivation and well-pulverized soil with proper management of water, air, thermal regime conditions are required for maize cultivation. Therefore, the annual conversion of soil from aerobic to anaerobic and then back to aerobic conditions is the key feature in the rice-maize cropping system (Mahajan and Gupta, 2009) other than that minimize risk, water conservation in a rotation system. Due to those reasons, the paddymaize rotation system showed a high sustainable value than the paddy monoculture system.

The cost of production has a positive regression coefficient, indicating a positive relationship with the sustainability index of the paddy monoculture system. Sustainable practices including improved usage of appropriate machinery, reduced lower quality inputs, adoption of IPM practices, adoption of GAP (Gill, 2018; Kassie et al., 2009). Hence these farmers need to utilize high-quality inputs and labor in a maximum way. Because of that cost of production has a positive relationship with sustainability.

\section{Factors Influencing Sustainability in Paddy Monoculture and Paddy-Maize Rotation Farming System}

Monetary income from outside of the farm has a positive regression coefficient, which means that the monetary income from outside of the farm is positively influenced by the sustainability of the paddy monoculture farming system. When non agricultural income increases, respondents have good economic status so that they can buy highquality inputs and they can utilize labor sources in a maximum way. Another thing is that they can spend money on higher education of their children, medicinal purposes, and can increase the quality of their daily food menu. Accordingly, when increasing non-agricultural income, the sustainability of the system is increased. The level of IPM also has a positive regression co-efficient which means it has a positive relationship with the sustainability of the system. IPM practices protect the health of the environment. IPM practices utilize biological, physical, and chemical methods in combination. But it tries to minimize the usage of chemical methods such as the application of pesticides and insecticides. This result can be concluded as, increasing the usage of IPM practices cause to increase the sustainability of the system. 
Table 2: Agricultural and Non-Agricultural Income in Paddy Monoculture and Paddy-Maize Rotation Systems

\begin{tabular}{|c|c|c|c|c|}
\hline Farming System & Mean & $\begin{array}{l}\text { Standard } \\
\text { Deviation }\end{array}$ & Minimum & Maximum \\
\hline \multicolumn{5}{|c|}{ Agricultural Income (Rs/acre/year) } \\
\hline Paddy monoculture system & $68,364.00$ & $10,702.00$ & $41,714.00$ & $108,550.00$ \\
\hline Paddy-maize rotation system & $166,770.00$ & $25,812.00$ & $118,552.00$ & $304,575.00$ \\
\hline \multicolumn{5}{|c|}{ Non-Agricultural Income (Rs/acre/year) } \\
\hline Paddy monoculture farmers & $133,680.00$ & $200,320.00$ & 0.00 & $960,000.00$ \\
\hline $\begin{array}{l}\text { Paddy maize rotational } \\
\text { farmers }\end{array}$ & $138,576.00$ & $214,930.00$ & 0.00 & $960,000.00$ \\
\hline
\end{tabular}

Table 3: Regression Results for Paddy Monoculture Farming System

\begin{tabular}{lcc}
\hline \multicolumn{1}{c}{ Factors } & Co-efficient & Probability value \\
\hline Average crop production & -0.000086 & 0.1592 \\
Cost of production & $\mathbf{0 . 0 0 0 0 0 4}$ & $<\mathbf{0 . 0 0 0 1 *}^{*}$ \\
Monetary income from the farm & -0.0000018 & 0.1141 \\
Monetary income from outside of the farm & $\mathbf{0 . 0 0 0 0 0 2 4}$ & $\mathbf{0 . 0 0 0 1 ^ { * }}$ \\
The salaries paid to farmworkers & -0.0000021 & 0.6543 \\
Hired labors & 0.0003037 & 0.9506 \\
The education level of the respondent & 0.0008574 & 0.8541 \\
Access to agrarian services & $\mathbf{- 0 . 0 0 4 5 9}$ & $<\mathbf{0 0 1} *$ \\
Usage of chemical fertilizer & 0.000374 & 0.3622 \\
Usage of agro-chemical & $\mathbf{0 . 0 6 7 6 1}$ & $\mathbf{0 . 0 0 1 1}$ \\
Level of GAP practiced & 0.06064 & 0.1299 \\
Level of IPM practiced & $\mathbf{0 . 0 9 4 6 8}$ & $\mathbf{0 . 0 2 6 7 ^ { * }}$ \\
\hline
\end{tabular}

*Significant at $5 \%$ level

Table 4: Regression Results for Paddy-Maize Rotation Farming System

\begin{tabular}{lcc}
\hline Factors & Co-efficient & Probability value \\
\hline Average paddy production & -0.000039 & 0.2798 \\
Average maize production & 0.0000013 & 0.3204 \\
Cost of production & 0.0000008 & 0.9573 \\
Monetary income from the farm & $\mathbf{7 . 0 5 5 3 3 9 E - 7}$ & $\mathbf{0 . 0 2 3 3}$ \\
The salaries paid to farmworkers & 0.0000021 & 0.2908 \\
Hired labors & -0.0002082 & 0.9348 \\
The education level of the respondent & -0.0040669 & 0.5879 \\
Access to agrarian services & $\mathbf{- 0 . 0 2 1 8 9}$ & $<\mathbf{0 . 0 0 0 1 *}$ \\
Usage of chemical fertilizer & -0.0068947 & 0.5387 \\
Usage of agro-chemical & $\mathbf{- 0 . 1 8 1 7 4}$ & $<\mathbf{0 0 0 1 *}$ \\
Level of GAP & 0.0412123 & 0.6475 \\
Level of IPM & $\mathbf{0 . 1 5 4 1 0}$ & $\mathbf{0 . 0 4 2 5}$ \\
\hline
\end{tabular}

*Significant at 5\% level 
Access to agrarian services has a negative regression co-efficient which means it has a negative relationship with the sustainability of the system. In this variable, the nearest distance was measured from the household to the Agrarian Service Center $(\mathrm{km})$. When the distance increased to Agrarian Service Center, they face difficulties accessing information services, quality inputs, and other government facilities. Because of that, when the distance increased to Agrarian Service Center, it decreases the sustainability index of the system. The usage of agrochemicals also has a negative regression coefficient indicates a negative relationship with the sustainability of the system. Due to pesticide, weedicide, and insecticide usage, beneficial organism population, and soil fertility are reduced. And also, it badly affects human health. When increasing the usage of agrochemicals, the sustainability of the system is decreased.

Regression results revealed that monetary income from the farm, distance to public infrastructure, usage of agrochemicals, and level of IPM significantly $(\mathrm{P}<0.05)$ influenced the sustainability of the paddy-maize rotation system.

Monetary income from the farm has a positive regression coefficient, which means it has a positive relationship with the sustainability of the system. If agricultural income increases, farmers have good economic status. They can spend more money on their cultivation in addition to other family needs such as education, medicine, etc. Increasing agricultural income causes to increase the sustainability of the system.

The level of IPM has a positive regression coefficient, indicate a positive relationship with the sustainability of the system. Usages of chemicals are minimized in IPM practices and it optimizes environmental health. Increasing usage of IPM practices causes to increase in the sustainability of the system.

\section{REFERENCES}

Department of Census and Statistics. (2016). Detail information on paddy statistics- Extent, Sown, Harvested (Gross and Net), Average yield and Production by districts. [Accessed 2 November 2019]. Available from: //http://www.statistics.gov.lk/agriculture/Pa ddy \%20Statistics/Paddy StatsPages/PADDY_ STATISTICS_2016-17_MAHA.pdf
Access to agrarian services has a negative regression co-efficient indicate a negative relationship with sustainability. The usage of agrochemicals also has a negative regression coefficient which means it has a negative relationship with the sustainability of the system. Due to the usage of pesticides, weedicide, and insecticide environment is polluted. Because of that beneficial organisms' population and soil fertility get diminished. Increasing usage of agrochemicals causes to decrease in the sustainability of the system.

\section{CONCLUSIONS}

Research results conclude as both paddy monoculture and paddy-maize rotation farming systems are sustainable while the paddy-maize rotation system reflects higher sustainability in the Anuradhapura district, Sri Lanka. Cost of production, monetary income from the outside of the farm, distance to agrarian services, usage of agrochemicals, and level of IPM are significantly influencing the sustainability of paddy monoculture farming system while monetary income from the farm, distance to agrarian services, usage of agrochemicals and level of IPM are significantly influencing on the sustainability of paddy-maize rotation system.

Although the paddy-maize rotation system reflects higher sustainability than the paddy monoculture system, this system needs further development on sustainability. Steady government policies and implementation mechanisms are required for credit facilities, subsidies, soil analysis, etc. Extension services, farmer awareness programs are needed to provide an enhanced knowledge about appropriate sustainable agricultural practices because most of the respondents did not know good agricultural practices (GAP) and integrated pest management (IPM).

Dumanski, J. and Pieri, C. (1996). Application of the pressure- state- response framework for the land quality indicators (LQI) program. Inland quality indicators and their use in sustainable agriculture and rural development, p 41. Proceeding of the workshop organized by the Land and Water Development Division FAO Agriculture Department, Agricultural Institute of Canada, Ottawa, 25-26 Jan 1996.

Food, Agriculture, Conservation, and Trade Act of 1990. [Accessed 05 November 2019]. Available 
from: https://www.agriculture.senate.gov /imo/media/doc/101-624\%20updated\% 2012518.pdf

Food and Agriculture Organization. (1990). Farming System and poverty. Analysis of Farming System. [Accessed 10 November 2019]. Available from: //http://www.fao.org/farmingsystems/ description_en.htm

Food and Fertilizer Technology Center. (2017)., 5F, 14 Wenchowst., Taipei 10648 Taiwan Crop production in paddy fields during the off season. [Accessed 20 January 2020]. Available from: /http://www.fftc.agnet.org/library.php? func=view\&id $=20110721110437$

Gill, D. (2018). How to keep insects, weeds and diseases out of your South Louisiana garden. May 24, 2018. [Accessed 12 January 2020]. Available from: https://www.nola.com/homegarden/index.ssf /2018/05/howto_keep_insects_weeds_and.ht $\mathrm{ml}$

Hanus, L. (2003). Sustainability analysis of agricultural systems. Acta Universitatis Agriculturae et Silviculturae Mendelianae Brunensis. LII(1), 103-112.

Kassie, M., Zikhali, P., Pender, J. and Kohlin, G. (2009). Sustainable Agricultural Practices and Agricultural Productivity in Ethiopia. Does agroecology matter? Environment for Development. Discussion Paper. End. pp, 09-12.

Nambiar, K.K.M., Gupta, A.P., Qinglin, F. and Li, S. (2001). Biophysical, chemical and socioeconomic indicators for assessing agricultural sustainability in the Chinese coastal zone. Agricultural sustainability in the Chinese coastal zone. Agriculture, Ecosystems and Environment. 87, 209-214.

Nazir, H., Kharkwal, S. Bardhan, D., Tripathi, S.C. and Kumar, A. (2017). Sustainability Assessment of Dairy Production Systems in Uttarakhand Hills of India, International Journal of Pure \& Applied Bioscience. 5(2), 215-229.

Ranaweera, N.F.C., De silva, G.A.C., Fernando, M.H.J.P. and Hindagala, H.B. (1988). Maize production in Sri Lanka. The CGPRT Centre. Regional co-ordination Center for Research and Development of Coarse, Grain, Pulses, Roots and tuber crops in the Humid Tropic of Asia and the Pacific, pp. 9-12

N. H. Rao and P. P. Rogers. (2006). Assessment of agricultural sustainability. Current Science. 61(4), 438-448.

Rasul, G. and Thapa, G.B. (2003). Sustainability analysis of ecological and conventional agricultural systems in Bangladesh. World development, 31(10), 1721-1741.

Rice Research and Development Institute, Bathalegoda. (2016). Information on Rice Cultivation. [Accessed 2 November 2019]. Available from: https://doa.gov.lk/rrdi/index.php?option=co m_sppagebuilder\&view=page\&id=42\&lang=en

Sala, S., Ciuffo, B. and Nijkamp, P. (2015). A systematic framework for sustainability assessment. Elsevier B.V. [Accessed 22 June 2018]. Available from: http://creative commons.org/ licenses/ by-NC-nd/4.0/

Vanloon, G.W., Patil, S.G. and Huger, L.B. (2005). Agricultural Sustainability: Strategies for Assessment, pp 30-232, Saga publications India Pvt Ltd, New Delhi: India. 